\title{
PTEN Gene Mutation Negative
}

National Cancer Institute

\section{Source}

National Cancer Institute. PTEN Gene Mutation Negative. NCI Thesaurus. Code C160488.

A genetic finding indicating that PTEN gene mutations have not been detected in a sample. 